Історико-політичні проблеми сучасного світу: Збірник наукових статей. - Чернівці: Чернівецький національний університет, 2019. - T. 40. - C. 67-75

DOI: $10.31861 / \mathrm{mhpi} 2019.40 .67-75$
Modern Historical and Political Issues: Journal in Historical \& Political Sciences. - Chernivtsi: Chernivtsi National University, 2019. - Volume. 40. - pp. 67-75 DOI: $10.31861 / \mathrm{mhpi} 2019.40 .67-75$

УДК: 327:399.9]"100"

(C) Liudmyla Novoskoltseva ${ }^{1}$

\title{
Globalization as Principal Vector of the World Development
}

Annotation. The article is focused on global subjects of the world community and consideration of geopolitical determinants that are dominant for the development of the new direction of the global community, as well as geopolitical centers of the modern world, geopolitical operations, their role and prospects for world ethnocultural civilizations.

Keywords.Globalization, global studies, geopolitics, civilization, world economy, Multinational Corporation, national borders, terrorism.

\section{Глобалізація як провідний вектор розвитку світу}

Анотація. У статті увага приділяється глобальним суб'єктам світового співтовариства, розглядаються геополітичні детермінанти, що $є$ головними для розвитку нового напряму функціонування світового співтовариства, а також геополітичні центри сучасного світу, геополітичні операції, їх роль і перспективи світових етнокультурних цивілізацій.

Ключові слова. Глобалізація, глобалістика, геополітика, цивілізація, світоваекономіка, ТНК, національні кордони, тероризм.

The problem formulation. The modern stage of human civilization development is characterized by the constant emergence of new trends and phenomena. Comprehension of what is happening, the formulation of assessments and conclusions, the preparation of forecasts for the development of the world, region, single country cannot be complete without geopolitical analysis. Ukraine is also experiencing the increasing influence of global political and socio-economic processes, characterized by multidimensional and ambiguous manifestations. Our state is only at the beginning of the road to restoring its positions in the world. In order to achieve a worthy geopolitical status of our country, it is important for the leadership of Ukraine to clearly define the geopolitical allies and opponents and build the line of behavior with them. By carrying out the geopolitical response to modern and future challenges and threats, Ukraine can act only by relying on historical experience, consistently defending its interests, preliminarily formulating and declaring them. The target objective for practical activities (and its expected result) is the world order corresponding to the interests of Ukraine.

The importance and significance of the research of the cooperation issue of non-institutional structures of global governance predetermines heightened interest in it from foreign and domestic political scientists, whose works are devoted to analyzing the impact of globalization processes on world integration actions. In particular, the views of foreign and domestic political scientists are based on theories of the power balance, communication, different-sized states, internationalization and interdependence, integration, competing leadership, etc., which provide for the analysis of the main cooperation characteristics of states at the international level.

Previous researches analysis. The study of the globalization process, influencing the development of the modern world is devoted to the works of such foreign scholars as Z. Bauman, U. Beck, P. Berger, L. Brown, P. Bourdieu, P. Buchanan, I. Wallerstein, B. Waldenfels, E. Giddens, E. Gore, T. Levitt, K. Omae, D. Stiglitz, O. Toffler, A. Utkin, D. Held, F. Fukuyama and others. Ukrainian scientists are also engaged in the study of globalization processes, in particular, since the mid-1990s. Since the 20th century in Ukraine the school of Ukrainian global studies has been founded under the leadership of O. Belorus, the representatives of which are V. Andrushchenko, A. Galchinsky, O. Gon-

\footnotetext{
${ }^{1}$ Candidate of Political Sciences, Associate Professor of the Department of Political Science and Law, Lugansk
} National Taras Shevchenko University, Ukraine. E-mail: 1_novoskolceva@mail.ru. 
charenko, L. Gubersky, B. Gungsky, O. Zernetskaya, V. Zlenko, E. Kaminsky, Yu. Kazak, V. Kopeika, O. Koppel, V. Kremen, S. Krymsky, Z. Lucishin, D. Lukyanenko, V. Manzhola, Yu. Makogon, E. Makarenko, M. Mikhalchenko, I. Novak, Y. Pavlenko, Y. Pakhomov, G. Pocheptsov, M. Rizhkov, O. Rogach, B. Parakhonsky, S. Sidenko, T. Starodub, S. Shergin, O. Shnirkov, A. Filipenko and others.

The issues, concerning the development of the present-day global governance structures and the strategies BRICS cooperation were under study of both foreign and Ukrainian scientists, in particular N. Abduli, R. Greenberg, V. Davydova, L. Kadisheva, B. Martynova, E. Makarenko, M. Mikhailova, K. Ohedy, M. Rakhmangulova, S. Ryazantseva, M. Ryzhkov, S. Savinsky, M. Titarenko, A. Tokarev, A. Shelepov, S. Shergin, M. Fesenk, I. Yarigin, and others.

Purposes and objectives of the research. One of the main factors for the development of civilization is globalization, the process that has encompassed the overwhelming majority of the modern world states, including Ukraine. The purpose of the research is that, under the influence of the number of global and local factors, the new geopolitical economic and civilizational situation is forming, which creates challenges and traps for the national state.

Main material presentation.At the last decades of the 20th century and at the beginning of the third millennium, globalization has become one of the main determinants of political development. Globalist terminology enters various spheres of scientific knowledge, it becomes the part of political practice, numerous conferences and round tables are held, monographs and collective collections devoted to the phenomenon of globalization are published.

The globalization process is worldwide. In this process, Ukraine is involved by virtue of objective and subjective reasons. At the same time, increased attention to the globalization processes in Ukraine was outlined only by the early 1990s, when these issues came into the picture, both in politics and in science. We can say that our scientists have just begun to study the issues that are already widely covered and presented in many works of foreign authors.

In the world community Ukraine was one of the key countries, but at the same time, it always had to overcome opposition and obstacles from other countries. Under the conditions of the hard eternal political struggle, Ukraine had to solve even more hard internal problems. The Soviet political elite had their own view of globalization and the nature of globalization processes. The USSR should be considered as a realized globalization project based on the ideas of universal unity, equality and fraternity, social and political justice, but the Soviet Union ceased to exist in the early 1990s of the last century. Ukraine faced the need for self-determination: either develop own new view of globalization, or follow the Western, neoliberal project of globalization. In addition, Ukraine is forced to find new schemes of mutual understanding with the whole world. The need for the comprehensive study of the role and place of Ukraine in the globalizing world is becoming obvious, if to take into account the complexity of the problems to be solved by the world community in the new millennium.

The transformation of the modern world was marked by the emergence of the serious factor in modern politics, which is globalization, which covers today many aspects of the life of the world community. Many researchers and politicians consider it as the general line of development, a new era in the history of mankind. So, in 1999-2000 World Bank report globalization is called the "dominant world process" 2 . However, according to the authors, it would be more accurate to say that on the planetary scale the dual process takes place, including two opposite trends. On the one hand, they have centripetal (integration) processes uniting people and nations of the planet, on the other hand the have centrifugal (disintegration) processes. In other words, the human world is both united and separated at the same time. For example, trade and communications ever more bind countries and peoples. But, at the same time, the lines of civilizational and cultural faults are deepen, internal geocivilizational integration (within countries and peoples of geocivilizations - Western, Islamic, Confucian-Buddhist, Latin American, etc.) is strengthened, rivalry of civilization between each other in assertion and spreading of their values (cultural, economical, technological) are deepen. In this case, it is rather necessary to talk about intra-civilization globalization. Yet, planetary globalization is a multidimensional process that has been spanning since early 21 st century.

Theories and concepts are created, scientific literature is published, national and international conferences are held, state leaders give their assessments and the globalization is discussed in global and

${ }^{2}$ Population and globalization / ed.-in-chief N.M. Rimashevskaya. - M.: Science, 2002. - p. 229. 
regional political and economic institutions. An anti-globalization movement has been formed and is actively acting and its manifestations of which gather hundreds of thousands participants at the same time and have the global scale.

The importance of globalization in modern society is evidenced by the occurrence of the new science - global studies. This fact does not mean at all that global processes have never existed before or nobody has dealt with them before. In fact, they were studied by various sciences: political science and economics, geopolitics and demography, ecology and cultural studies, etc. Consequently, globalization is the complex science, based on the fundamental knowledge of many sciences. The reasons for the transformation of global studies from the field of knowledge into the independent science are the rapid growth of globalization processes, the increase in political, economic, financial, technological and information integration and the sharpening of environmental challenges that threaten human existence itself. Global studies should not be understood as the separate or special scientific discipline, which often arise, as general, as the result of the differentiation of scientific knowledge or at the meeting of related disciplines. It is born by opposite - integration processes common for modern science, and represents the field of research and knowledge, where various scientific disciplines, mostly in close interaction with each other, each from the standpoint of its subject and method, analyze various aspects of globalization, offer solutions global issues, considering them both in isolation from each other, and as the integral system.

Modern globalization is more remind of the world Westernization and the almost overt receipt of the multiple benefits from the participating in globalization processes by advanced countries and transnational companies (TNCs), which are much larger than other participants have. The term "globalization" was first proposed by the professor at Harvard Business School T. Levitt in the article "Market Globalization", published in 1983 in "Harvard Business Review" magazine ${ }^{3}$. By this concept, he defined the convergence of markets around the world through the action of the new form of enterprise, called global firms. Globalization and technology became, in his opinion, the two main factors determining international relations. In his monograph "The Marketing Imagination", published the same year, T. Levitt calls the technology as "the powerful force that makes the whole world move towards uniformity"4, as a result, the new commercial reality arises, global markets for globally standardized products occurs, as well as gigantic markets of such magnitude and scale that previously could not be imagined.

The concept of "globalization" was developed in the works of Japanese researcher in the field of management strategy K. Omae. In the book "Triad Power", published in 1985, he calls "Triad" an imaginary triangle formed by the United States, Japan and Western Europe with the adjacent geographical areas, representing the global market with 600 million consumers which absorbs more than 3/4 of world technology 5 .

In the book "What Is Globalization?" U. Beck aptly notes: "Globalization has definitely been the most widely used (and including in the wrong way) as the key word in discussions at recent years and will be at the coming years. However, it is also one of the words that is most rarely defined and most often misinterpreted, being at the same time the most politically effective concept" ${ }^{\text {" }}$. U. Beck believes that it is necessary to distinguish a number of dimensions of globalization, and any list of them should include communication technologies, ecology, economy, organization of activities, culture and civil society. He believes that "globalization means that borders are becoming noticeably less significant for everyday behavior in different dimensions of the economy, information, ecology, technology, intercultural conflicts and civil society. Money, technology, goods, information and toxic substances "cross" the borders as if they do not exist"'.

From the point of view of economists, globalization is defined as "the appearance of the globalized economy in which national economies are divided and then re-connected in the system of agreements and processes directly at the international level"'. In this globalized economy, the boundaries of na-

\footnotetext{
${ }^{3}$ Theodore Levitt. The Globalization of Marketing // Harvard Business. Review. - May-Juin, 1983. - P. 92-93.

${ }^{4}$ Ibid.

${ }^{5}$ M. Cheshkov. A look at globalization through the prism of globalism // World Economy and International Relations. - 2001. - № 2. - p. 52-57.

${ }^{6}$ U. Beck. What is globalization? // Beck U. - M.: Progress-Tradition, 2001. - pp. 19-20.

${ }^{7}$ Ibid.

8 Ibid.
} 
tional economies are no longer significant, and this economy "follows its own logic, which differs from the logic of economic relations between independent national entities. Multinational enterprises are removed from local anchors, the movement of capitals is shooting out of the national category, and states lose domination over their currency"9.

Politicians believe that globalization can be viewed as the rise in their power of the new "multicenter" world face to face with the existing world, where the state, closely connected with it, rules ${ }^{10}$. This new world is based on non-state, or transnational, relations. According to geographers, globalization can be analyzed as the process of forming at the international level of the space that is the product of joint distribution, exchange and communication between different parts of humanity.

There is also no consensus on when the globalization process began. Some researchers believe that the process of globalization began at the 20th century, others that at the era of the Great Geographical Discoveries, third - that earlier and the fourth binds this process exclusively to the latest achievements of the scientific and technological revolution. Therefore, the Organization for Economic Cooperation and Development (OECD) distinguishes three stages in the process of globalization: a) internationalization (from the middle of the 19thcentury), corresponding to the development of export flows; transnationalization (since the beginning of 1945). This process is associated, with the rapid growth of direct investment flows and their placement in foreign countries; globalization (since the 1980s), expressed in the development of global networks of production, financing and information ${ }^{11}$.

The globalization of the world economy, characterized by significant growth and liberalization of cross-border movements of goods, services and capital, the intensive exchange of information and technology, has led to the kind of "blurring of national borders". Its components are transnational production, the global financial system, the international trading system that build on the agreed-upon rules, the forming information space.

In his work "The End of Nation State. The Rise of Regional Economics" K. Omae insists that states not only lose their ability to control the exchange rate and protect their currencies, but in the current conditions they no longer carry out real economic activity, not being the main active participants in the global economy. In support of this, he draws upon his conclusions regarding the four determining factors that he calls the "Four Ands" 12 .

The first "AND" is investments that are no longer geographically limited and, crossing borders, come to where the most attractive investment opportunities exist. If a decade ago, according to the author, the flow of cross-border funds was mainly from the government to the government or from the multilateral financial organization, now the vast majority of investments are private and, as a rule, exclude the involvement of national governments in this process.

The second "AND" is the industry in its orientation that is also becoming more global. Modern multinational, transnational corporations (TNCs) are not guided by the interests of the state, but by the attractiveness of the markets and contribute to the transfer of technology and management innovation.

The third "AND" is information and information technologies, which enable companies to operate in different parts of the world without the need to create the business system in each country where they are represented.

The fourth "AND" is individual consumers, who also have become more global in their orientation and want to have better and cheaper products, not paying attention to where it is produced. The mobility of these combined four "ANDs", according to K. Omae creates opportunities for viable economic units in any part of the world to attract everything that is necessary for their development without the assistance and mediation of the state. Since in all global markets, the four "ANDs" act on their own, states no longer play the role of "market makers". These fundamental changes are changing the economic picture of the world ${ }^{13}$.

K. Omae believes that if the unlimited movements of the four "ANDs" make the mediating role of the state obsolete, the restrictions necessary for making global decisions begin to correspond to "inarti-

\footnotetext{
${ }^{9}$ U. Beck. What is globalization? // Beck U. - M.: Progress-Tradition, 2001. - pp. 19-20.

${ }^{10}$ A.Stukalo, T. Avdeeva. Globalization of the world economy // International life. - 2010. - № 5. - P. 49-56.

${ }^{11}$ Padalitsya M.V. The mechanism of mutual relations of transnational corporations with national economics. URL: http://intkonf.org/padalitsya-mv-mehanizm-vzaemodiyi-transnatsionalnih-korporatsiy-znatsionalnimiekonomikami/.

${ }^{12}$ Ohmai Kenichi. The End of Nation State: the Rise of Regional Economics. - N.Y.: The Free Press, 1995. ${ }^{13}$ Ibid.
} 
ficial political borders of the state, but to more focused geographic units, such as Hong Kong and the adjacent part of southern China or Kansai region around Tokyo, or Catalonia, that is, the regions where work is done and real markets flourish." The scientist calls these zones as "regional states". Moreover, they can be entirely inside or go beyond the borders of nation states and are natural economic zones in the "world without borders ${ }^{14}$."

To the "regional states" Japanese scientist also refers Northern Italy, the Upper Rhine, the Silicon Valley and the Gulf zone in California, Singapore-Johor triangle (the southern state of Malaysia) and the neighboring islands of Indonesia, the South Korean city of Busan, Tokyo with the surrounding areas, etc. These regions, although geographically limited, are huge in their economic impact, and their main factors are not the population, but the necessary components for successful participation in the global economy. They are powerful engines of development because their primary orientation is the global economy, and the defining characteristics are created by the requirements of the global economy. "Regional states" are the gateway to the global economy, their appearance fundamentally changes the global logic of the actions of transnational corporations.

The ideologists of globalization are investing in this concept, in addition to economic, financial, informational and other types of integration, the growing influence of international financial and economic institutions (IMF, WTO, etc.), transnational corporations, prestigious organizations (for example, the Trilateral Commission that is the meeting of America, East Asia and Western Europe), limiting the possibilities of nation-state development, including the erasure of state borders that "restrain" financial and migration flows, development and adoption of "generally accepted supranational rules of behavior" 15 . For example, K. Zegbers understands by globalization "narrowing (or even disappearance) of the opportunity to develop in special way, to shy away from the torrent (protruded) road, and, consequently, to reduce the opportunity for the government or society to consciously choose some kind of their own path"16.

Instead of their own path, supporters of globalization offer countries the path of internationalization, and more precisely, westernization. They consider it (the path of westernization and market regulation) to be the most correct and progressive, which "is resisted only by the incorrigible fundamentalists who remain in deep defense". M. Cheshkovgives a comprehensive definition of this complex phenomenon, reflecting many of its components: "Globalization is: the establishment of the global financial and economic space of the global scale market; post-industrial stage of countries development and the appearance of the global information space based on the latest computer and media technologies; homogenization and universalization of the world; - attempts of universal distribution of the unified system - values of neoliberal sense; the politically demanded concept of the formation of the unipolar world and the formation of the new world order ${ }^{17}$ ".

From the point of view of geopolitics, we can say that globalization is the tool for securing the victory of the West in the "cold war" with the East and deriving from it material, financial and geopolitical benefits. It can be said that globalization is a social theory, ideology and practice that consolidates the positions of strong states and supranational entities (in the economic, financial, technological, information spheres). Therefore, a reaction to globalization does not look as accidental - not only positive, but also negative: Huge masses of people in many countries and even some state leaders call themselves antiglobalists.

In fact, there are a lot of global problems on the planet, they require solution, which is reflected in globalization processes: first of all, economic, since trade is expanding all over the world, capital flows, goods and services are increasing, the economic interdependence of countries around the world is growing, and at the same time the level of poverty does not decrease, the gap between rich and poor is growing deeper; global nature acquired environmental problems that are fateful for planet Earth; demographic shifts, increasing migration flows (about one out of every thirty people on the planet migrants - people who do not live at home) are of global importance; the global information space is

\footnotetext{
${ }^{14}$ Ohmai Kenichi. The End of Nation State: the Rise of Regional Economics. - N.Y.: The Free Press, 1995.

${ }^{15} \mathrm{Zb}$. Brzezinsky. Selection. Global domination or global leadership // Brzezinski Zb. - M.: International Relations, 2004. - p. 126.

${ }^{16}$ K. Zegbers. Stitching a quilt... (Chances and risks of globalization in Russia) // Pro et Contra. - 1999. - No. 4.P. 65.

${ }^{17}$ M. Cheshkov. A look at globalization through the prism of globalism // World Economy and International Relations. - 2001. - № 2. - p. 52-57.
} 
being created, the global information and communication network, primarily through space communications and the "global web" (the Internet), encompassing huge masses of the global population and unprecedentedly affecting mass consciousness both positively and destructively; there are significant sociocultural shifts with diverse and difficult to predict consequences affecting almost all regions and most countries. According to a number of scientists (S. Huntington, N. Zotova, G. Anilionis, A. Prazauskas and others), one of the options for development in this regard is the clash of civilizations. Many believe that the inter-civilization war between Western civilization and the Islamic one is already under way (since September 11, 2001) and that its consequences are catastrophic; the destructive consequence of the globalization of the modern world is terrorism. It is not just a negative, but complex, multidimensional and socio-political phenomenon that has long gone beyond national borders and turned into the global scale threat. The scale of terrorism is growing. If, according to UN data, 380 international terrorist acts were committed in 1999 (233 people died) ${ }^{18}$, then in $2000-423$ (405 people died), and in $2004-3.2$ thousand terrorist attacks and 28 thousand dead ${ }^{19}$. The sad tendency persists. In connection with the expansion of the boundaries of this negative phenomenon, even the notion of "terrorist internationalism" is appeared, referring primarily to the "International Islamic Front of Jihad against the Jews and the Crusaders", headed until 2011 by Osama bin Laden, with branches in the USA, Afghanistan, Pakistan, Somalia, Egypt, Yemen, Algeria, Tunisia, Lebanon, Tajikistan, Chechnya, Azerbaijan, India and the Philippines.

Globalization weakens the role of the state as the main political factor of international relations and expands the possibilities of new, illegitimate political players in the face of international terrorism and transnational organized crime merging with it. The increasing level of globalization of all spheres of social development and communication capabilities of mankind provides opportunities to use the achievements of modern civilization (including freedoms and human rights, as well as high technologies) not only for specious purposes.

A serious danger is seen in the that the inability of many countries and peoples of the world to confront developed countries economically, militarily and technologically compels them to look for alternative ways to ensure their own security. Here lies the source of manifestations of terrorism or insufficient anti-terrorism activities, the desire to acquire nuclear weapons or other weapons of mass destruction. Taking into account the lack of access by most countries to nuclear technology, they can take a more "simple" way - to direct efforts to the development of chemical and biological weapons.

Suffice it to recall how the postal envelopes with anthrax powder terrified the USA. Bioterrorism is the multifaceted phenomenon with transboundary and transnational character.

Modernization, through which globalization is mostly carried out, is not always met with joy, in many countries and cultures it causes rejection. For example, in Muslim countries, in response to the development of modernization processes, fundamentalism and related terrorism flourish. According to N. Moiseev, "the rejection of liberalism leads to the lag in the field of industrial production, in the development of new ideas and technologies, devotes these people, so to speak, to the fate of Neanderthals", and since "no nation will agree with such finale of their own history, then it will take up arms". The scientist believes that if the world community does not find the strength to deeply restructure its organization, then modernization processes can lead to the emergence of "hot fronts" whose lines will correspond to civilizational faults ${ }^{20}$.

The availability of high technology has significantly increased the threat of nuclear, chemical, biological, informational and other types of modern terrorism. As noted by U. Beck, the modern world, technologically progressing, "widens the global gap between the language of foreseeable risks, within which we think and act, and the world of endless threats, which we also create"21.

Some researchers believe that war is the way of defusing aggressive energy accumulated due to social circumstances, with the critical level of aggressiveness being achieved by each generation. And since the presence of nuclear weapons did not allow the current generation to throw out aggressive

\footnotetext{
${ }^{18}$ B. Putilin. Terrorist internationalism. - Zhukovsky; // Putilin B.G. - M.: Kuchkovo Pole, 2005. - p. 159-160.

19 V. Antipenko. Terrorism in the existing world system. Geo-economic approach // Theories of world development and anti-terrorism law. Matching logic [Text]: Monograph / V.F. Antipenko; Security Service of Ukraine, In-t operational activities and state security. - K.: Publishing house "YUNONA-M", 2007.- p. 147.

${ }^{20}$ N. Moiseev. Ecological crisis and civilizational conflicts // Problems of global security. - 1995. - p. 139.

${ }^{21}$ U. Beck. Political Dynamics in the Global Risk Society // Beck U. - World Economy and International Relations. 2003. - № 5. - p. 11.
} 
energy, it is looking for other ways out ${ }^{22}$. That is why the issue of determining the origins of the challenges and threats associated with manifestations of aggressiveness, extremism and terrorism, and not just funding to fight against biological, chemical and electronic terrorism, as the United States did in 1999 , having allocated 2.8 billion for this purpose, US dollars is relevant ${ }^{23}$.

At the end of 20th century computer terrorism emerged as the consequence of globalization and the wide spread of information technologies. Computer terrorism is understood as unlawful access to computer information placed on the single computer or computer network, carried out to modify, destroy this information or familiarize with it, to create a situation in which the operation of this computer or computer network goes beyond the prescribed standard parameters, the danger of damage to property, loss of life, or the onset of any other socially dangerous consequences (destabilization of installation, pressure on the authorities, disruption of the functioning of the transport and banking infrastructure, threat to personal safety, etc.) are arise. According to a survey of residents of world megalopolises, conducted by Euro Worldwide Agency, $45 \%$ of respondents are concerned about the threat of computer terrorism.

A kind of initiator of the development of terrorism in the global scale appears to be Western civilization, its economic, technological, military and cultural expansion, the propaganda of violence, the imposition of consumer values, low-standard morality and lack of spirituality. All this, carried out under the specious cover of slogans about freedom, human rights and democracy, which return as boomerang in the form of manifestations of anti-Western aggression and terrorism. S. Huntington, who, in his geopolitical model of the "clash of civilizations", predicts the division of the world into "the West and the rest of the world ${ }^{24}$. "There is no doubt that to solve global problems (and there are really a lot of them), it is necessary to combine the efforts of the states of the world and their citizens, but not on the basis of dictation of some and subordination of others, but on equal and parity grounds, which will allow to void many contradictions and conflicts, the critical level of which is close to explosive.

Globalization is considered by various researchers from different perspectives: as qualitatively new condition of the world economy and world society, as vector of world development and form of transition to the information civilization. It is clear that there is a strong interdependence between geopolitics and globalization. As noted by Y. Knyazev, "globalization is the continuation in the modern conditions of, old as the hills, policies of expansionism. At first there was a struggle for the division of the world, then for its border"25. Therefore, from the geopolitical point of view, globalization is the longterm expansion of the West on the planetary scale on the grounds of advantages in aggregate national strength: "The large world powers call it globalization: no country in the world that has no right to determine its own path of economic development in the interests of its own nation"26.

Some researchers even more elaborate this concept, viewing globalization as the specially designed program of US dominance as the leader of the West in the international arena. "From the standpoint of geopolitics, globalization is the new form of implementing the US geopolitical strategy to maintain and strengthen their influence in the world" ${ }^{27}$. Globalization is an effective tool for establishing the new world order, since expansion is carried out using almost all components of national power, only their order and priority are changed.

The current stage of globalization is associated with the spread of communication and information technologies. Globalization is based not only on the growth of flows of people and goods, but also on the intensification of the exchange of information and knowledge. The introduction of new information technologies is aimed at the unification of lifestyle and the processing of mass mind. A standardization of thinking and lifestyle facilitates the management of dependent states, territories and nations.

\footnotetext{
${ }^{22}$ R.A. Baron. Human Aggression. - N.Y., 1996.

23 Y. Miller and Broad W. Cliton Sees Threat of Genn Terrorism // International Herald Tribune. 1999, Jan. - p. 23-24.

${ }^{24}$ S. Huntington. "East: unicity versus universalism" // Philosophical thought. - 1999. - № 1-2. - P. 82-100.

${ }^{25}$ Yu.Knyazev. Transfer to the market economy at the background of globalization // Post-socialist countries in the context of globalization: Collection of the materials of the International Scientific conference - M., 2001. p. 366.

${ }^{26} \mathrm{~V}$. Senchagov. Economic security: geopolitics, globalization. Self-preservation and development // V. Senchagov - M.: Finstatinform, 2002. - p. 23.

${ }^{27}$ Globalization. - L., NY, 1996.
} 
The peculiarity of the modern stage of globalization is that the influence and power of transnational corporations (TNCs) is increasing. Their part in the global economy is constantly increasing. TNCs have become states within the state. Their role is especially high in developing countries that do not have the consolidated national elite. The activities of international organizations are closely connected with globalization: WTO, IMF, World Bank Group, etc. They undoubtedly depend, first of all, on the developed countries, and the strengthening of their influence means the strengthening of the influence of the West. The influence of TNCs is parallel to the growing influence of these organizations, which negatively affects the economic development of dependent countries.

As for the national power of the dependent states, due to the reduction of their sovereignty, it is constantly and steadily decreasing. European nations are rapidly losing their identity due to the growth of uncontrolled migration. The main geopolitical problem that arises in connection with this is how long this situation will last, because such huge difference in the level and quality of life between developed and developing countries creates global instability and provokes violence.

Conclusions and prospects for further research. Summarizing what has been said, it should be noted that in the context of globalization the cultural and civilizational media and the spiritual sphere become the main sphere of the geopolitical struggle in the 21st century. Destruction or absorption of world civilizations and change of their essence is one of the main tasks of the West and financial elites. At the same time, ethnocultural civilizations are beginning to enter the international arena as leading global players. The inability of modern states to resist global mafia structures also makes it necessary for larger sociopolitical players (civilizations and civilizational unions) to enter the world arena. The world ethnocultural civilizations (regional civilization associations) still play a minor role in the formation of planetary processes. At the same time, geopolitical centers of power are actively forming on the cultural and civilizational basis.

\section{References}

1. Beck U. What is globalization? The mistakes of globalism - the answers to globalization / Ulrich Beck; under general editorship of A. Filippova; translation from German by A. Grigorieva and V. Sedelnik. - M.: Progress-Tradition, 2001.

2. Beck U. Political Dynamics in the Global Risk Society // Beck U. - World Economy and International Relations. 2003. - № 5. - P. 11.

3. Baron R. Human Aggression. - N.Y., 1996.

4. Globalization. - L., NY, 1996.

5. Knyazev Yu. Transfer to the market economy at the background of globalization // Postsocialist countries in the context of globalization: Collection of the materials of the International Scientific conference - M., 2010.

6. Levitt Theodore. The Globalization of Marketing // Harvard Business. Review. - May-Juin, 1983. - P. 92- 93.

7. Miller Y. and Broad W. Cliton Sees Threat of Genn Terrorism // International Herald Tribune. 1999, Jan. - P. 23-24.

8. Antipenko V. Terrorism in the existing world system. Geo-economic approach // Theories of world development and anti-terrorism law. Matching logic [Text]: Monograph / V.F. Antipenko; Security Service of Ukraine, In-t operational activities and state security. - K.: Publishing house "YUNONA-M", 2007.

9. Moiseev N. Ecological crisis and civilizational conflicts // Problems of global security. -2005 .

10. Population and globalization / ed.-in-chief N.M. Rimashevskaya. - M.: Science, 2012.

11. Padalitsya M.V. The mechanism of mutual relations of transnational corporations with national economics. - URL: http://intkonf.org/padalitsya-mv-mehanizm-vzaemodiyi-transnatsionalnihkorporatsiy-znatsionalnimi-ekonomikami/.

12. Putilin B.G. Terrorist internationalism. - Zhukovsky; // Putilin B.G. - M.: Kuchkovo Pole, 2009.

13. Senchagov B. Economic security: geopolitics, globalization. Self-preservation and development // V. Senchagov - M.: Finstatinform, 2007.

14. Stukalo A., Avdeeva T. Globalization of the world economy // International life. -2013 . - № 5. - P. 49-56. 
15. Udovik S. Globalization: symeotic approaches // Udovik S.L. - M.: "Refl-Book", K.: "Vekler", 2012. - 480 p.

16. Huntington S. "East: unicity versus universalism" // Philosophical thought. - 1999. - № 1-2. P. 82-100.

17. Cheshkov M. A look at globalization through the prism of globalism // World Economy and International Relations. - 2011. - № 2. - P. 52-57.

18. Shvidanenko O.A. Is globalization a factor in the development of world polarization? / O.A. Shvidanenko // Mechanism of regulation of the economy, the economy of nature use, the economy of the enterprise and the organization of production: Collection of scientific publications of Sumy State University. - Sumy: CumDU, 2002. - No. 1-2. - C. 230-239.

19. ShevtsovaYa. O. Scale of the activities of transnational companies (TNCs) in the global market. - URL: http://intkonf.org/shevtsova-yao-masshtabi-diyalnosti-transnatsionalnih-kompaniytnk-nasvitovomurinku/.

20. World Investment report 2013: Global value chains: investment and trade for development. URL: http://data.worldbank.org/data-catalog/world-development-indicators.

21. World Development Indicators, The World Bank. - URL: http://data.worldbank.org/datacata $\log$ /world-development-indicators. 